\title{
Spatio-temporal persistence of top predator hotspots near the Antarctic Peninsula
}

\author{
Jarrod A. Santora ${ }^{1,2,3, *}$, Richard R. Veit ${ }^{4}$ \\ ${ }^{1}$ Antarctic Ecosystem Research Division, Southwest Fisheries Science Center, National Marine Fisheries Service, NOAA, \\ La Jolla, California 92037, USA \\ ${ }^{2}$ Farallon Institute for Advanced Ecosystem Research, 101 H Street, Suite Q, Petaluma, California 94952, USA \\ ${ }^{3}$ Center for Stock Assessment Research, University of California, Santa Cruz, 110 Shaffer Road, Santa Cruz, California 95060, USA \\ ${ }^{3}$ Biology Department, College of Staten Island, City University of New York, 2800 Victory Boulevard, Staten Island, \\ New York 10314, USA
}

\begin{abstract}
We quantified species richness and abundance of seabirds and marine mammals in order to identify marine areas that are persistently attractive to top predators. Shipboard surveys across a $150000 \mathrm{~km}^{2}$ grid off the Antarctic Peninsula were conducted once or twice each year from 2003 to 2011 during which the distribution and abundance of top predators were mapped. We hypothesized that spatial organization of species richness and abundance hotspots reflect persistent habitat use and are regionalized according to distance from land and oceanographic boundaries. To test this, we used a new hotspot variance metric based on the percentage of time that the species richness or abundance estimate at any one location is greater than 1 standard deviation above the long term means for the entire survey grid. Species richness hotspots were based on all species sighted, while abundance hotspots were based on concentrations of 16 species: 13 seabirds (penguins, petrels and albatrosses), 1 pinniped and 2 baleen whales. Species abundance hotspots reflected 2 major groupings - those with oceanic and coastal origins. We identified 15 richness hotspots, 9 of which were in proximity to the southern Antarctic Circumpolar Current front; the 6 others were associated with major breeding colonies and the location of 2 submarine canyon systems. Our approach integrates temporal and spatial variances over 14 individual surveys and provides useful reference points for identifying ecologically important areas, refining food web models and developing spatial management of and conservation strategies for marine ecosystems.
\end{abstract}

KEY WORDS: Abundance $\cdot$ Antarctic $\cdot$ Conservation $\cdot$ Hotspot $\cdot$ Persistence $\cdot$ Richness $\cdot$ Seabirds $\cdot$ Marine mammals $\cdot$ Marine spatial management

\section{INTRODUCTION}

Inhabiting the largest ecosystem on earth, seabirds and marine mammals are truly global organisms and sentinels of ocean ecosystem state (Tittensor et al. 2010, Sydeman et al. 2012). With conservation of seabirds and marine mammals becoming increasingly urgent, there is a need for the quantitative designation of hotspots - areas characterized by persistent, elevated abundance and species richness (Piatt et al. 2006, Sydeman et al. 2006, Davoren 2007, Santora et al. 2010, Nur et al. 2011, Suryan et al. 2012). Top predator hotspots can be identified either by tracking individuals and quantifying how much time they spend in each encountered habitat (Block et al. 2011), or alternatively, via shipboard surveys documenting the abundance and species richness of predators measured in each habitat (Yen et al. 2006, Santora et al. 2010, Nur et al. 2011, Suryan et al. 2012). However, persistence of hotspots is rarely quantified. Using a shipboard approach, we present information on the persistence of predator hotspots near the 
Antarctic Peninsula based on data collected during 14 shipboard surveys between 2003 and 2011. This is a region of rapid climate change (Meredith \& King 2005 ) that has experienced serial depletion of marine mammals (Fraser et al. 1992, Ballance et al. 2006), and is becoming a growing ecotourism destination (Tin et al. 2008, Lynch et al. 2010) and a commercial krill fishery (Kawaguchi et al. 2006, Nicol et al. 2012). Therefore, we need to know where top predators and their prey are persistently concentrated to benefit marine spatial management and conservation (Reid et al. 2004, Santora et al. 2012a,b, Sigler et al. 2012).

The hotspot concept is useful in studies of highly mobile organisms such as seabirds and mammals, because the extreme variability characteristic of the distributions of marine organisms makes it highly unlikely that any single mapping would be truly representative. As a consequence, one needs repeated standardized surveys to determine those areas that persist in their attractiveness to top predators. However, the hotspot concept applied to top predators in marine ecosystems has received somewhat mixed definitions. According to Sydeman et al. (2006), marine hotspots are defined as 'sites of critical ecosystem linkages between trophic levels'. Piatt et al. (2006) defined hotspots as a 'relatively small area in which we expect to find animal aggregations repeatedly'. Davoren (2007) defined hotspots as 'areas where high abundance of species overlap in space and time'. Indeed, there have been many uses of the term hotspot, but the commonality of these definitions is some aspect of spatio-temporal persistence (Gende \& Sigler 2006, Sigler et al. 2012, Suryan et al. 2012). We decided to quantify both abundance hotspots for individual species, and richness hotspots for the entire community. We calculated these from a suite of highly replicated shipboard surveys sampled over many years (Santora et al. 2010, 2012a). Using a grid-based approach, we define hotspots of species richness and abundance as locations with anomalies that exceed the mean for the entire study region by 1 standard deviation in a given survey, and define their frequency of occurrence by estimating the percentage of time a hotspot occurs over many surveys (Suryan et al. 2012).

Motivation for this study was based on the following: (1) the Antarctic Peninsula marine ecosystem has been impacted by human disturbances over the past 2 centuries (e.g. commercial whaling; krill fishing; Fraser et al. 1992, Trivelpiece et al. 2011, Nicol et al. 2012) and is experiencing rapid climate change (Meredith \& King, 2005); (2) krill stocks have declined and gelatinous salps are increasing (Atkinson et al. 2004); (3) ecosystem-based management of the Southern Ocean krill fishery will benefit from the delineation of top predator hotspots so that overlap between fishing vessels and predators is minimized (Reid et al. 2004, Santora et al. 2010, 2012a) and; (4) the likelihood of seabirds and marine mammals exhibiting extremely dense aggregations at sea is high and leads to difficulties in modeling their spatial distribution that is not yet resolved (Oppel et al. 2012, Sigler et al. 2012). Our overarching objective was to quantify the location of persistent species richness and abundance hotspots. We applied a new variancebased metric to identify hotspots by accounting for their persistence (consistent or frequent occurrence) of anomalies through time (Suryan et al. 2012). We tested the hypothesis that the geospatial variability of species richness and abundance hotspots relates to distance from land and oceanographic boundaries.

\section{METHODS}

\section{Study area}

The US Antarctic Marine Living Resources (AMLR) program conducts surveys on a fixed grid along north-south transects with stations spaced at $\sim 55 \mathrm{~km}$ intervals across a $150000 \mathrm{~km}^{2}$ area surrounding the South Shetland Islands at the northern tip of the Antarctic Peninsula (Fig. 1). The study area is located within the narrowest latitudinal stretch of the Southern Ocean (closest point between South America and Antarctica). The hydrography and circulation of this region is complex and variable and reflects inputs and mixing of waters from the Antarctic Circumpolar Current (ACC) within Drake Passage, the western portion of the Weddell gyre, and upstream regions along the western Antarctic Peninsula that enter through Gerlache Strait and western Bransfield Strait (Amos 2001, Thompson et al. 2009). The rugged bathymetry of the region (which includes the continental shelf around the islands, deep basins of Bransfield Strait, and the South Shetland Trench and Shackleton Fracture Zone ridge in Drake Passage) provides additional hydrographic and circulation variability (Orsi et al. 1995; Fig. 1). Physical oceanographic conditions around the South Shetland Islands exhibit a broad range of water mass characteristics because of the mixing of the ACC, Scotia Sea, Antarctic coastal current and the higher latitude waters of the Weddell Sea (Orsi et al. 1995, Amos 2001, Thompson et al. 2009). Relevant to this study, the southern Antarctic 


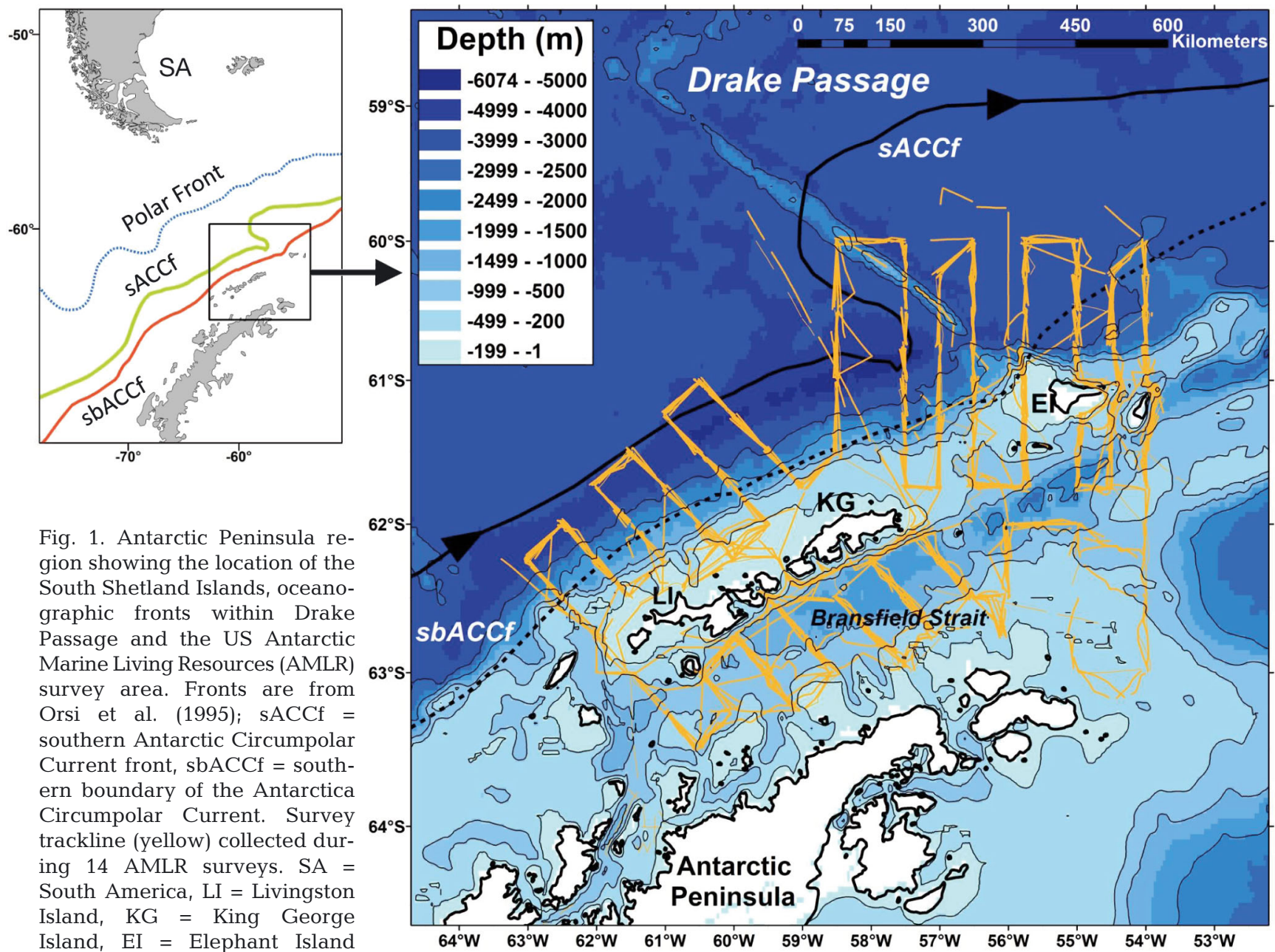

Circumpolar Current front (sACCf) and its southern boundary (sbACCf) (Fig. 1) is an ecologically important oceanographic frontal zone for whales and krill (Tynan 1998, Atkinson et al. 2008).

During January-March 2003 to 2011, we conducted 14 surveys to map the distribution and relative abundance of seabirds, pinnipeds and cetaceans (Table 1 , Fig. 1). Our coverage of transects was replicated annually and within the summer season; occasionally there were 2 surveys per year (Table 1, Fig. 1). The grid design enabled sampling of a variety of habitats, including the extensive insular shelf systems around the archipelago, submarine canyons, shelf-break regions, deep basins of Bransfield Strait and the oceanic waters of southern Drake Passage; see Fig. 2 for a summary of survey effort
Table 1. Summary of survey effort for predator observations conducted on 14 Antarctic Marine Living Resource (AMLR) program surveys. Only survey effort that falls within the 54 regularly sampled grid cells is presented

\begin{tabular}{|cccccc|}
\hline Year & Survey & Days & Survey dates & $\begin{array}{c}\text { Survey } \\
\text { hours }\end{array}$ & $\begin{array}{c}\text { Distance } \\
(\mathrm{km})\end{array}$ \\
\hline 2003 & 1 & 16 & 16 January - 28 January & 129.27 & 2394.1 \\
& 2 & 16 & 10 February - 25 February & 113.73 & 2106.7 \\
2004 & 1 & 17 & 13 January - 31 January & 126.60 & 2344.6 \\
2005 & 1 & 15 & 15 January - 30 January & 121.02 & 2241.3 \\
& 2 & 16 & 22 February - 9 March & 107.03 & 1982.2 \\
2006 & 1 & 16 & 16 January - 31 January & 114.07 & 2112.6 \\
2007 & 1 & 18 & 8 January - 26 January & 148.10 & 2742.8 \\
2008 & 1 & 23 & 13 January - 5 February & 154.47 & 2860.8 \\
& 2 & 17 & 16 February - 5 March & 128.93 & 2387.8 \\
2009 & 1 & 18 & 12 January - 29 January & 165.12 & 3058.0 \\
2010 & 1 & 13 & 25 January - 9 February & 84.88 & 1571.9 \\
& 2 & 14 & 19 February - 6 March & 90.30 & 1666.8 \\
2011 & 1 & 21 & 14 January - 4 February & 188.22 & 3481.7 \\
& 2 & 15 & 17 February - 5 March & 98.48 & 1823.8 \\
\hline
\end{tabular}




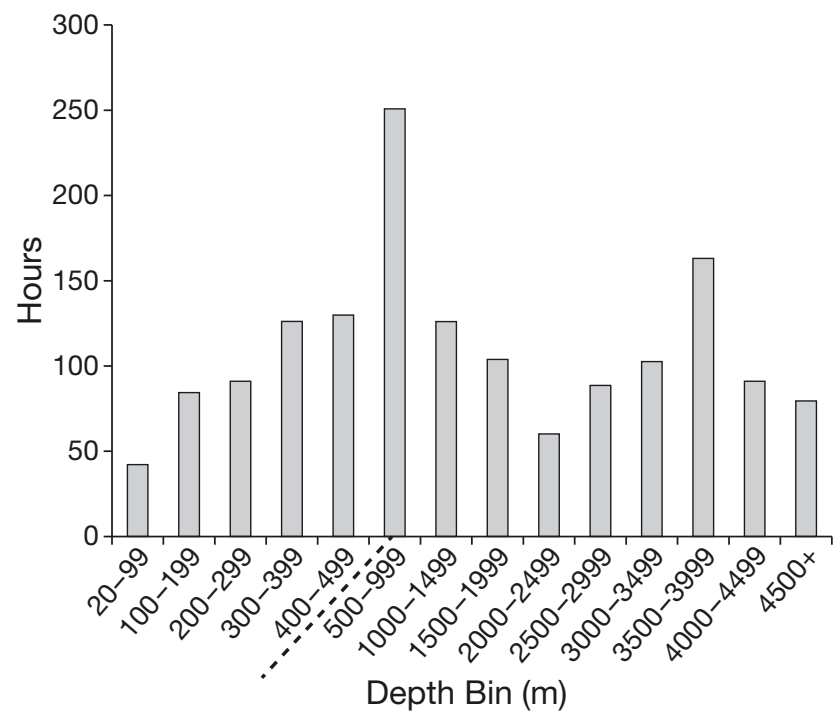

Fig. 2. Summary of survey effort in relation to bathymetry; dashed line indicates change from $100 \mathrm{~m}$ to $500 \mathrm{~m}$ depth bin size, due to sampling of shelf-break and slope regions

according to different sea depth bins. Previously, a subset of this dataset was used to identify the location and spatial association of baleen whale and krill demographic hotspots (Santora et al. 2010). Moreover, the grid design has permitted the description of habitat use for poorly known cetaceans (Santora \& Brown 2010, Santora 2012) as well as modeling mesoscale structure and spatial organization of krill hotspots (Santora et al. 2012a).

\section{Predator surveys}

Sighting data on predator abundance and distribution were continuously collected during daylight hours between sampling stations along fixed transects (Fig. 1). Additional survey methods are described in Santora et al. $(2009,2010)$ and Santora \& Reiss (2011). Ship speed during transits was generally 10 knots $\left(\sim 18.6 \mathrm{~km} \mathrm{~h}^{-1}\right)$, and observers used hand-held binoculars to scan for predators from a height of $\sim 13 \mathrm{~m}$ above sea level. Each sighting was assigned a time and a spatial position from the ship's global positioning system. Sea surface state (Beaufort scale) and visibility (e.g. fog, glare) were continuously monitored and effort during unfavorable conditions (e.g. Beaufort >5, heavy fog) was excluded prior to analysis. Counts of seabirds were made within a $90^{\circ}$ arc from $300 \mathrm{~m}$ ahead of the ship to one side while underway (Camphuysen \& Garthe 2004). Shipfollowing birds were recorded when first encountered and ignored thereafter. Surveys of whales were conducted using standard line transects by trained observers each year. All recorded cetacean sightings were observed in a $180^{\circ}$ arc forward of the vessel and up to $3 \mathrm{~km}$ away. For each whale sighting, a bestestimate spatial position, bearing and a perpendicular distance estimate to the ship's trackline were logged (Buckland et al. 1993). Observations of seals were collected in a $180^{\circ}$ arc forward of the vessel and included position and group size (Santora 2013). True to all shipboard surveys of air-breathing marine animals, there is an inherent issue of detectability associated with the animal's behavior and sea state conditions (Southwell et al. 2008). Although line-transect (distance) sampling was not used to estimate absolute marine mammal density, sightings were collected consistently across all 14 surveys to estimate a standardized relative abundance index.

We selected the 16 most numerous and frequently sighted top predator species for quantifying abundance hotspots (Table 2, Appendix 1; Hunt et al. 1990). Three species of marine mammals (2 baleen whales, 1 pinniped) and 13 species of seabirds were selected based on their overall abundance, representing a variety of different foraging behaviors and life histories. All of the species examined in this study feed on small zooplankton and nekton (e.g. krill, copepods, mesopelagic fish, squid), but differ in their feeding behavior due to locomotion and body size (Croxall \& Prince 1980, Laws 1985). Baleen whales predominantly feed on krill and exploit dense patches of krill throughout the water column (Laws 1977). Penguins and pinnipeds are pursuit diving predators and select a variety of krill and fish species (Croxall \& Prince 1980, Reid et al. 2006). The flying seabirds examined in this study are restricted to feeding near the sub-surface and select a variety of prey (Croxall \& Prince 1980). For comparative purposes, we focused on 2 species each of baleen whales (Balaenopteridae), penguins (Spheniscidae), albatross (Diomedeidae), storm petrels (Hydrobatidae) and 6 species of petrels (Procellaridae). Because of the difficulty identifying prions (Pachyptila spp.) at sea, counts of unidentified prion, Antarctic prion ( $P$. desolata) and thin-billed prion ( $P$. belcheri) were pooled into 'prion species'. Our analysis of species richness hotspots were based on all species observed (Appendix 1).

\section{Analysis}

All shipboard trackline and predator sightings were combined in a geographic information system. The shipboard trackline was extensive and covered open 
Table 2. Summary of species, total sightings (S), total individuals (Ind.) and individuals per unit effort (IPUE) observed at sea for 14 US Antarctic Marine Living Resources (AMLR) surveys (January - March, 2003 to 2011). SE = standard error, SD = standard deviation, $\mathrm{CV}=$ coefficient of variation, ${ }^{*}$ Species that breed at the South Shetland Islands or Antarctic Peninsula

\begin{tabular}{|c|c|c|c|c|c|c|c|}
\hline \multirow{2}{*}{ Common name } & \multirow{2}{*}{ Scientific name } & \multirow[t]{2}{*}{$\mathrm{S}$} & \multirow{2}{*}{ Ind. } & \multicolumn{4}{|c|}{ IPUE $\left(\right.$ No. $\mathrm{h}^{-1}$ cell $^{-1}$ survey $\left.^{-1}\right)$} \\
\hline & & & & Mean & $\mathrm{SE}$ & $\mathrm{SD}$ & $\mathrm{CV}$ \\
\hline Cape petrel $^{*}$ & Daption capense & 8523 & 70703 & 42.85 & 6.56 & 22.75 & 0.53 \\
\hline Antarctic fulmar* & Fulmarus glacialoides & 5955 & 34700 & 22.79 & 5.54 & 19.19 & 0.84 \\
\hline Black-browed albatross & Thalassarche melanophrys & 2966 & 5003 & 3.51 & 0.84 & 2.92 & 0.83 \\
\hline Grey-headed albatross & Thalassarche chrysostoma & 844 & 966 & 0.64 & 0.14 & 0.49 & 0.76 \\
\hline Southern giant petrel ${ }^{*}$ & Macronectes giganteus & 1628 & 2334 & 1.43 & 0.21 & 0.74 & 0.51 \\
\hline White-chinned petrel & Procellaria aequinoctialis & 1468 & 2085 & 1.18 & 0.46 & 1.62 & 1.37 \\
\hline Blue petrel & Halobaena caerulea & 1154 & 2159 & 1.04 & 0.34 & 1.19 & 1.15 \\
\hline Prion & Pachyptila spp. & 2736 & 5108 & 2.11 & 0.71 & 2.45 & 1.16 \\
\hline Wilson's storm petrel ${ }^{*}$ & Oceanites oceanicus & 5169 & 7646 & 5.04 & 0.74 & 2.59 & 0.51 \\
\hline Black-bellied storm petrel ${ }^{*}$ & Fregetta tropica & 6046 & 8165 & 4.48 & 0.84 & 3.22 & 0.72 \\
\hline Chinstrap penguin** & Pygoscelis antarctica & 4877 & 28066 & 17.09 & 2.12 & 7.35 & 0.43 \\
\hline Gentoo penguin* & Pygoscelis papua & 275 & 1612 & 1.16 & 0.46 & 1.61 & 1.38 \\
\hline South polar skua* & Catharacta maccormicki & 531 & 579 & 0.38 & 0.05 & 0.18 & 0.47 \\
\hline Humpback whale & Megaptera novaeangliae & 767 & 1346 & 0.92 & 0.14 & 0.48 & 0.53 \\
\hline Fin whale & Balaenoptera physalus & 543 & 1084 & 0.76 & 0.33 & 1.16 & 1.51 \\
\hline Antarctic fur seal* ${ }^{*}$ & Arctocephalus gazella & 1517 & 2261 & 1.46 & 0.30 & 1.05 & 0.72 \\
\hline
\end{tabular}

water (there was no pack ice present), bays, inlets and passages between islands. Survey effort was binned into 54 cells, each $0.5^{\circ}$ latitude $\times 1^{\circ}$ longitude in dimension $\left(\sim 2860 \mathrm{~km}^{2}\right)$. The ship's trackline (at $1 \mathrm{~min}$ intervals) was plotted to determine the number of hours sampled per cell and survey, as an index of effort (Table 1, Fig. 1). Only cells that were sampled during at least 7 surveys and for at least $1.5 \mathrm{~h}(\sim 27.78 \mathrm{~km})$ were used in subsequent analyses. Using these criteria, a total of 546 cells and $1684 \mathrm{~h}$ were sampled over 14 surveys for a mean \pm SD of $38 \pm 11$ cells survey $^{-1}$ and $3 \pm 0.3 \mathrm{~h} \mathrm{cell}^{-1}$ survey $^{-1}$, respectively (Table 1 ). This cell size has been used extensively in this region to examine net-based spatial distribution and abundance patterns of Antarctic krill (Atkinson et al. 2004, 2008), associations between hotspots of baleen whales and krill (Santora et al. 2010), and mesoscale structure of krill hotspots (Santora et al. 2012a).

A 3-step process, similar to that of Suryan et al. (2012), was used to quantify temporal and spatial variance and anomaly persistence of a cell's value of species per unit effort (SPUE) and individuals per unit effort (IPUE). This procedure integrates variability and anomaly persistence into a metric that, when mapped, produces a seascape of resolved peak species richness and abundance values (hotspots). First, for each survey, rates of SPUE and IPUE are calculated (1) by dividing the total number of species (out of 54 species; see Appendix 1) or individuals of a given species (Table 2) by the amount of hours surveyed per cell and then subtracting the survey mean and dividing by the survey standard deviation to normalize each survey (e.g. z-score; Table 2):

$$
S P U E_{i, j} \text { or } I P U E_{i, j, z}=\left[\left(N_{i, j} / E_{i, j}\right)-S_{j} x\right] / S_{j} S d
$$

where $N_{i, j}$ is the number of species sighted (or relative species abundance; $z$ refers to the species under consideration in $I P U E_{i, j, z}$ ) in cell $i$ during survey $j$, $E_{i, j}$ is the number of hours sampled per cell, $S_{j} x$ and $S_{j} s d$ are the survey mean and standard deviation of species richness and abundance in a given survey. Second, the grand mean and standard deviation of $S P U E_{i, j}$ and $I P U E_{i, j, z}$ is estimated for each cell over all surveys. Within a given survey, hotspots are cells with species richness or abundance anomalies that exceed the grand survey mean by $>1 \mathrm{SD}$. Third, the percentage of time a cell displayed an anomaly $>1$ SD above the grand mean is tabulated. This threshold of $>1$ SD is a common measure for variance of anomalies in space-time series analysis and has previously been used to map persistence of remotelysensed chlorophyll a (chl a) (Suryan et al. 2012) as well as krill and whale hotspots (Santora et al. 2010, 2012a). Cells with higher percentages reflect locations where species richness or species abundance is persistently higher than the baseline standardized anomaly. For mapping purposes, persistence is classified to permit comparison of hotspot spatial distribution patterns. Classes, based on percentage of surveys, are $0-15 \%, 15-30 \%, 30-45 \%$ and $>45 \%$.

Our first objective was to examine whether groups of species exhibit similar spatial persistence based on the distribution of their abundance hotspots. We used 2 complementary multivariate statistical procedures to address this objective regarding species abundance hotspots: hierarchical cluster analysis and 
principal component analysis $\left(\mathrm{PCA}_{i}\right.$ Legendre \& Legendre 1998). Estimates of species hotspot persistence (per cell, based on percentage of surveys) were approximately normally distributed (KolmogorovSmirnov test, $\mathrm{p}>0.05$ ) and were inputted into PCA and cluster analysis as a Pearson correlation matrix. Meaningful principal components were determined by inspecting eigenvalues (e.g. Scree plot) and percent variance explained (Legendre \& Legendre 1998). Cluster analysis (Ward's method with Euclidean distance metric and standard deviation scaling) was used to produce a dendrogram indicating groups of species sharing similar hotspot persistence.

Our second objective was to determine how the persistence of species richness and abundance hotspots varied relative to distance to land and the hydrographic boundaries. Tynan (1998) suggested that the southern boundary of the ACC front has ecological significance for whales throughout the Southern Ocean, and Bost et al. (2009) discussed how fronts are likely regions of elevated trophic transfer and therefore important foraging areas for both seabirds and mammals. Therefore, we tested the hypothesis that the persistence of species richness and abundance hotspots are spatially associated with the ACC front and its southern boundary, and inversely related to distance from land. To test this hypothesis, we correlated a cell's persistence value (percentage of surveys with an anomaly $>1 \mathrm{SD}$ ) with distance to land and hydrographic features. We calculated the nearest distance $(\mathrm{km})$ from each cell centroid to the position of the southern ACC front and its southern boundary (Orsi et al. 1995) and nearest land. For perspective, the mean distance from land across all cells is $112.2 \pm 90.4 \mathrm{~km}$, and the mean distance to the southern ACC front and its southern boundary is $222.9 \pm 140.5$ and $134.1 \pm 100.8 \mathrm{~km}$, respectively. We used a randomization procedure (bootstrap and Monte Carlo analysis; 10000 randomizations) to calculate Spearman rank correlations and probabilities, with an emphasis on significant negative correlations as indicators of association (i.e. less distance between hotspot and feature).

\section{RESULTS}

\section{Species richness hotspots}

The mean ( \pm SD) number of species sighted per cell was $12.1 \pm 2.3$ and ranged from 5.4 to 18.9 for all 14 surveys. All richness hotspots exhibited persistence values $>50 \%$, indicating that species rich-

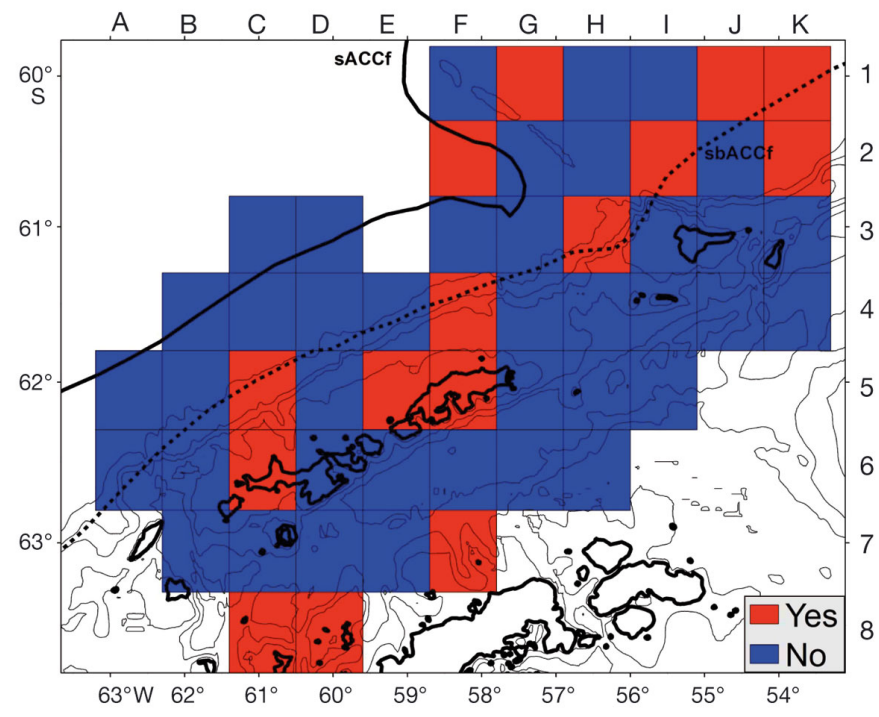

Fig. 3. Location of species richness hotspots. All richness hotspots were persistent for $>50 \%$ of all surveys; red square (Yes) indicates richness hotspots

ness within these locations was generally high on nearly half of total surveys (Fig. 3). Species richness hotspots were located throughout the study area ( $\mathrm{n}=15)$, but were generally more common north of the South Shetland Islands in association with the southern ACC front and its southern boundary (Fig. 3). There were 3 richness hotspots associated with the location of 2 submarine canyon systems; cells C5 and C6 near Livingston Island and cell F7 in Bransfield Strait adjacent to the northwestern tip of the Antarctic Peninsula (see bathymetry in Fig. 1). There were 3 species richness hotspots (cells E5, F4 and F5) located to the east, north, and south of King George Island (Admiralty and Maxwell Bays). In addition, there were 2 adjacent richness hotspots at the southern edge of the study area near a confluence formed by the mixing of waters from Bransfield and Gerlache Straits (cells C8 and D8; Fig. 3).

Table 3. Principal component analysis (PCA) for the persistence of abundance for 16 species; eigenvalues and total variance for PCA factors

\begin{tabular}{|lcc|}
\hline PCA factor & Eigenvalue & $\%$ Total variance \\
\hline 1 & 5.24 & 32.72 \\
2 & 2.39 & 14.91 \\
3 & 1.54 & 9.60 \\
4 & 1.42 & 8.89 \\
5 & 1.04 & 6.47 \\
6 & 0.89 & 5.57 \\
\hline
\end{tabular}



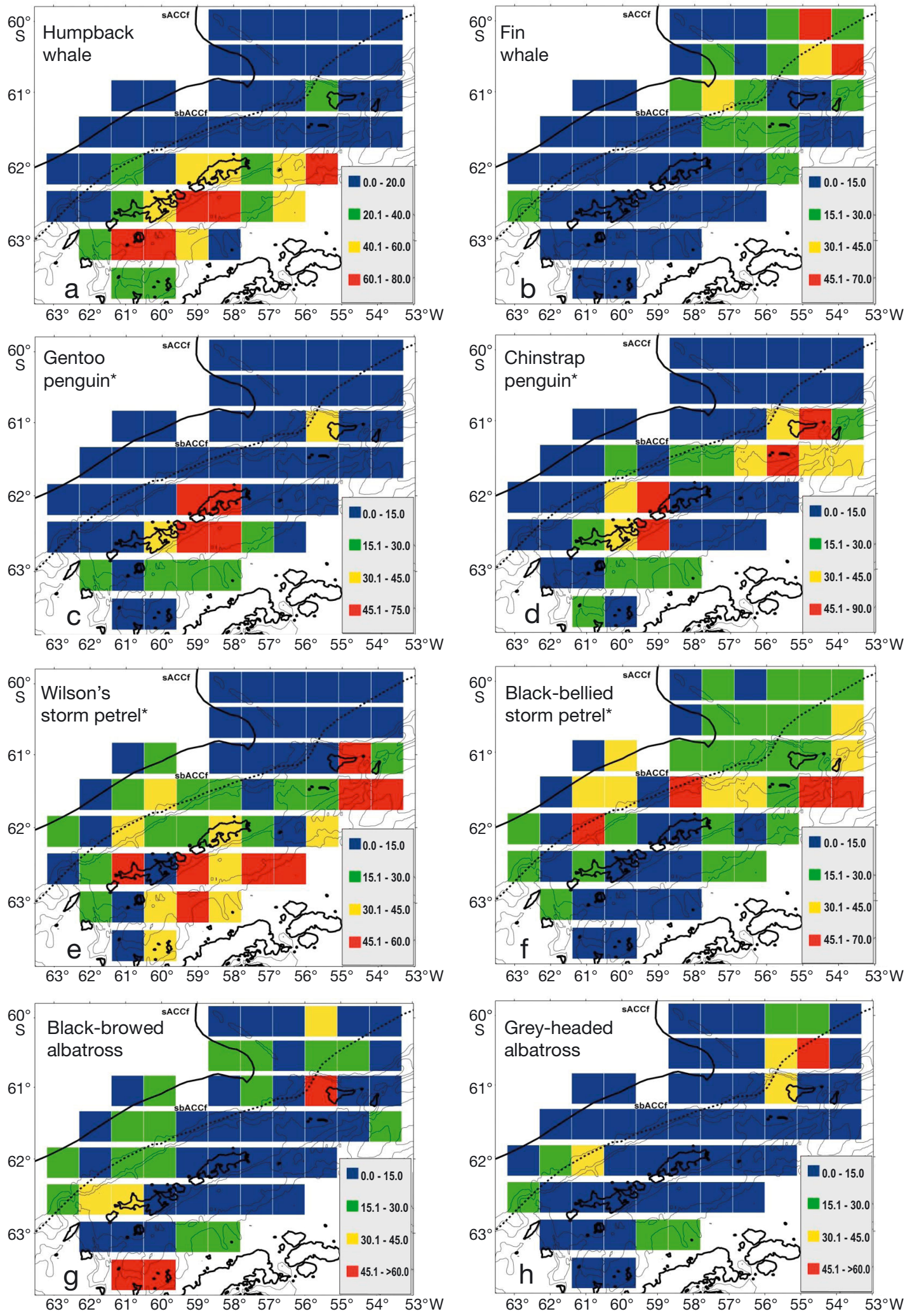

Fig. 4. Classified persistent abundance hotspots (percentage of time cell anomaly exceeds 1 standard deviation above the mean) of (a) humpback whale, (b) fin whale, (c) gentoo penguin, (d) chinstrap penguin, (e) Wilson's storm petrel, (f) blackbellied storm petrel, $(\mathrm{g})$ black-browed albatross, (h) grey-headed albatross, (i) cape petrel, (j) Antarctic fulmar, (k) Antarctic fur seal, (l) south polar skua, (m) blue petrel, (n) prions (o) white-chinned petrel and (p) southern giant petrel. *Species breeds in study region and therefore some hotspot locations may represent land-based breeding colonies 

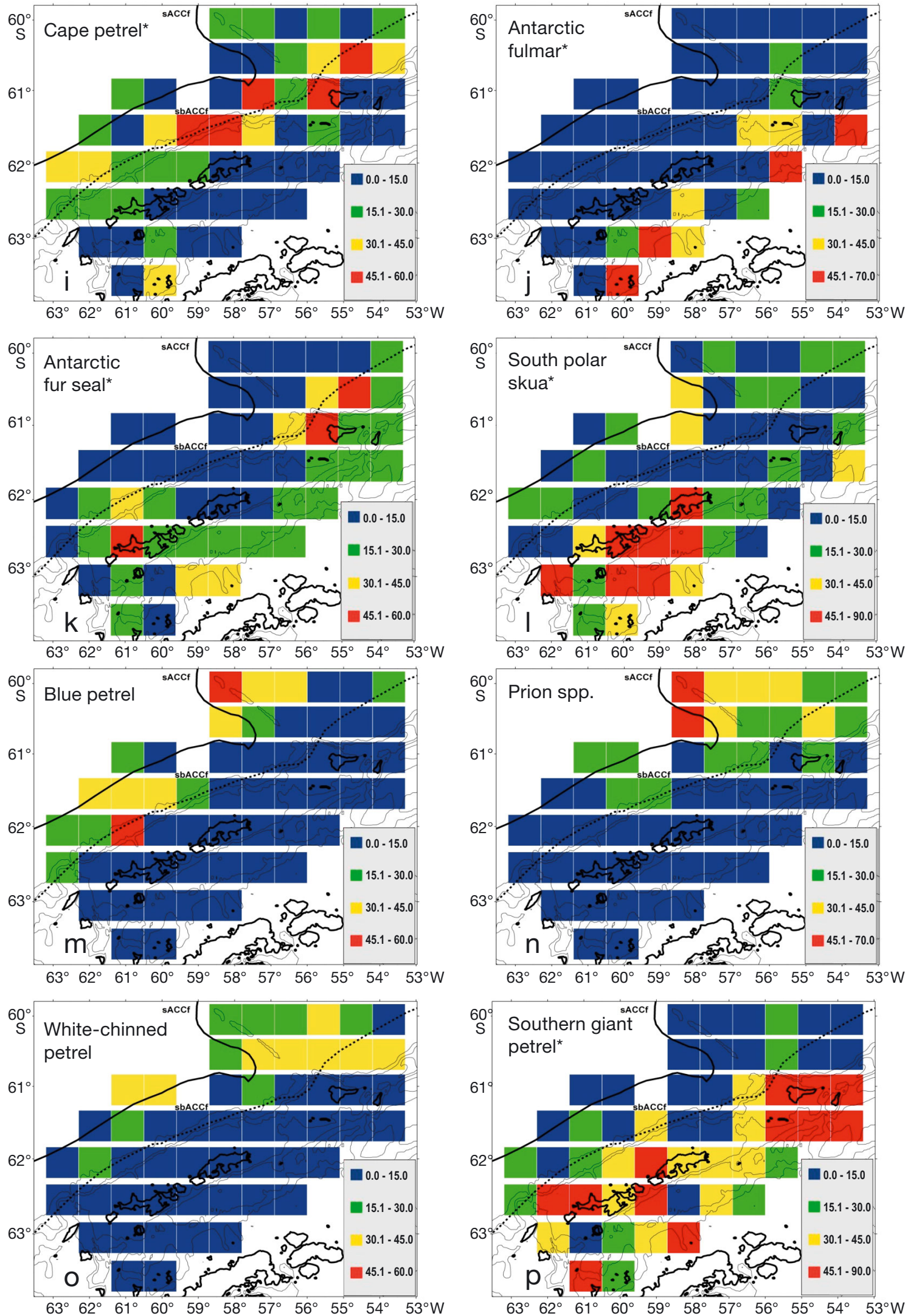

Fig. 4 (continued) 


\section{Species abundance hotspots}

We identified abundance hotspots as those areas that consistently displayed abundance anomalies exceeding 1 standard deviation above the long term spatial mean $>45 \%$ of the times surveyed. We identified abundance hotspots for 16 top predators and generally showed 2 areas of concentration related to coastal and oceanic habitats (Figs. 4a-p \& 5). Cluster analysis and PCA of species abundance hotspots revealed 2 groupings that reflect their preferred foraging habitats and for some species, probable landbased breeding locations (Table 3, Fig. 5). There is an 'Oceanic Drake Passage' group, including fin whale, black-bellied storm petrel, prions, white-chinned petrel, blue petrel, Antarctic fur seal, grey-headed
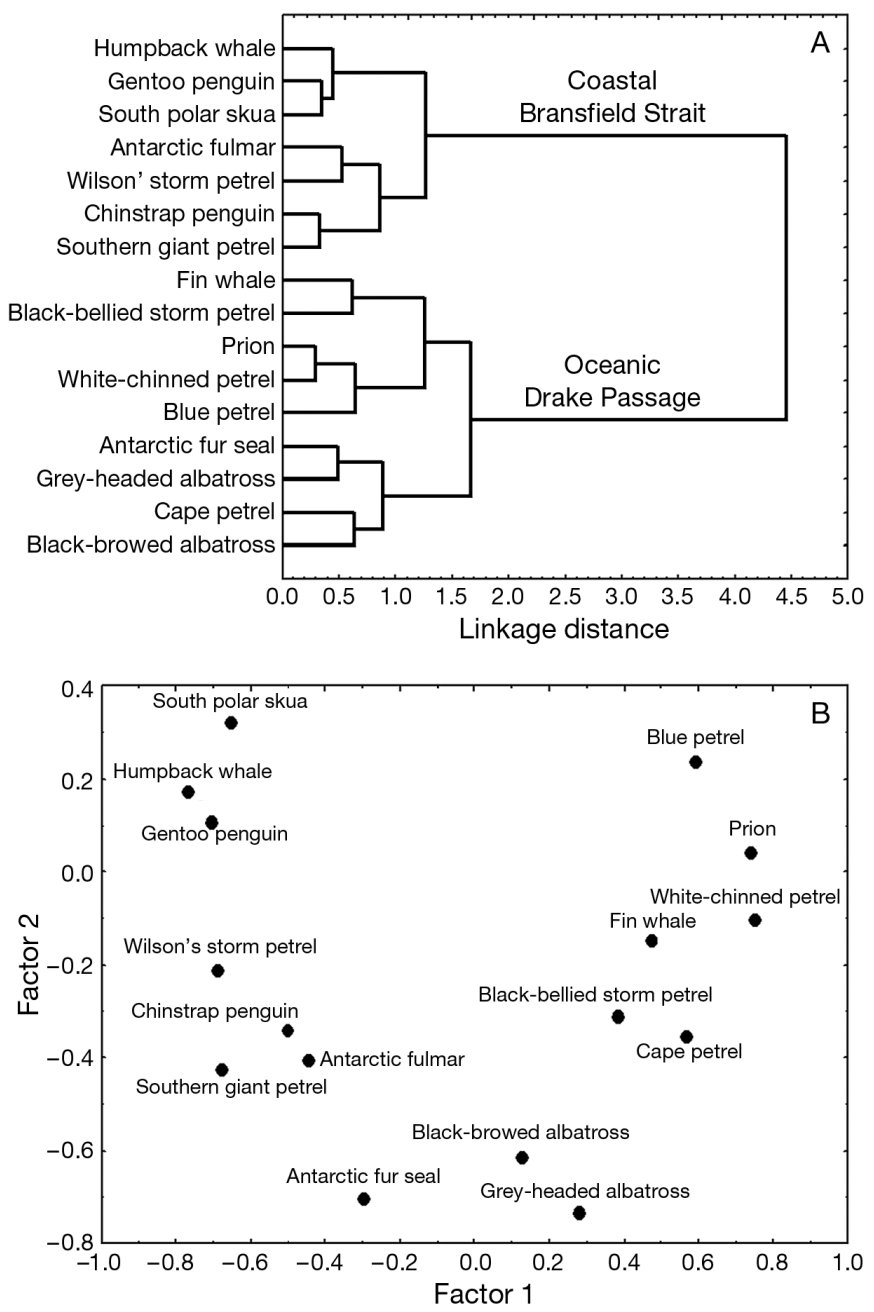

Fig. 5. Species assemblages defined based on their persistence of abundance as determined by (A) hierarchical cluster analysis and (B) ordination of factors from principal component analysis albatross, cape petrel and black-browed albatross; and a 'Coastal Bransfield Strait' group, including humpback whale, gentoo penguin, chinstrap penguin, south polar skua, Antarctic fulmar, Wilson's storm petrel and southern giant petrel (Fig. 5). In addition, cell loadings of PC1 and PC2 dichotomized by positive and negative values illustrate this apparent spatial segregation (Fig. 6).

We found that closely related species, such as gentoo and chinstrap penguins and black-browed and grey-headed albatrosses, aggregated together in the same hotspots (Fig 4c,d,g,h). By contrast, other
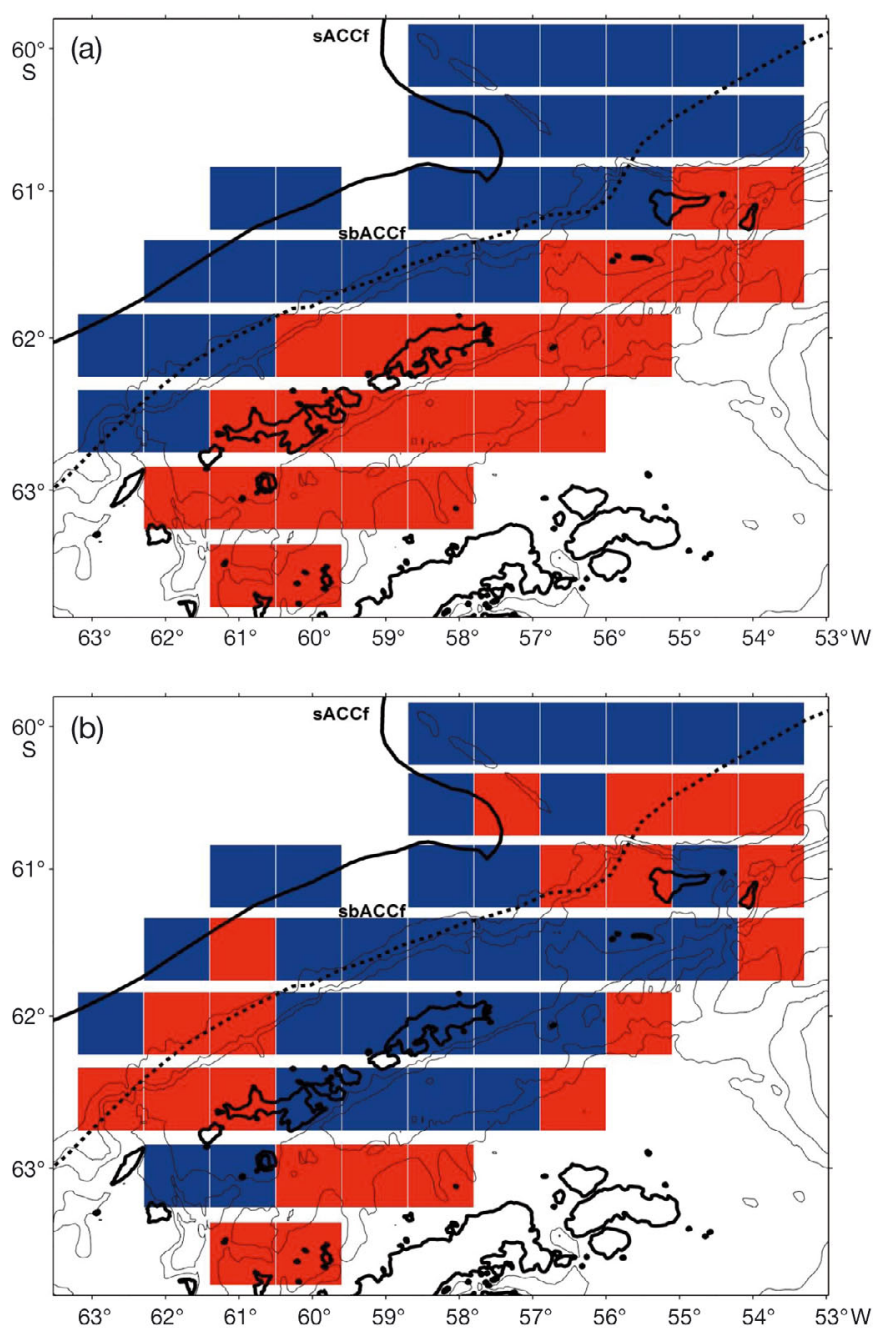

Fig. 6. Plot of principal component analysis (PCA) factor loadings per cell (grouped by positive [red] and negative [blue] values) for (a) PC1, illustrating species assemblages based on abundance hotspots and showing a separation of the 'Oceanic Drake Passage' from 'Coastal Bransfield Strait' (see Fig. 1) and (b) PC2, showing regionally specific areas to the spatial persistence of top-predators due to island locations and unique circulation or water mixing/retention 
species pairs appeared to segregate into different hotspots. This apparent segregation seemed to be based on oceanographic habitats. For example, hotspots of humpback whales and Wilson's storm petrels were concentrated within Bransfield Strait, whereas hotspots of fin whales and black-bellied storm petrels were concentrated in southern Drake Passage (Fig. 4a,b,e,f). The closely related and similarly sized cape petrel and Antarctic fulmar are frequently observed in aggregations numbering in the thousands, yet their hotspot locations were separated according to oceanic and coastal origins. Abundance hotspots of cape petrels occurred mainly within the southern ACC frontal zone (Fig. 4i), whereas abundance hotspots of Antarctic fulmars were chiefly in southern Bransfield Strait (Fig. 4j).

We found that some species exhibited more hotspots than other species (Fig. 7). For example, blackbellied storm petrels, southern giant petrels, Antarctic fur seals and humpback whales showed more hotspots, while species such as grey-headed albatross, gentoo and chinstrap penguins, and Antarctic fulmar had fewer (Fig. 7). The medium and high persistence species abundance hotspots (yellow and red cells) were summed across all 16 species per cell to reveal the importance of a cell (Fig. 8). Several cells proved attractive to multiple species. For example, the cell that includes the western half of Elephant Island (I3) includes hotspots for 6 species (greyheaded albatross, black-browed albatross, cape petrel, fur seal, southern giant petrel, gentoo and chinstrap penguins) and the one that includes the eastern portion of Livingston Island (C6) includes hotspots for 6 species (humpback whale, gentoo and chinstrap

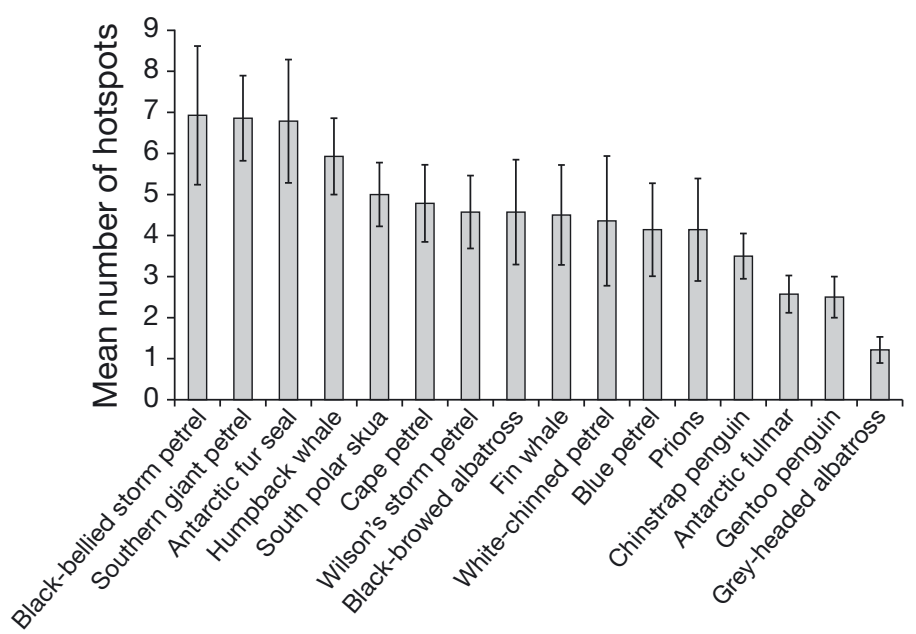

Fig. 7. Mean number $( \pm \mathrm{SD})$ of species abundance hotspots over 14 surveys. Species are sorted relative to frequency of hotspots

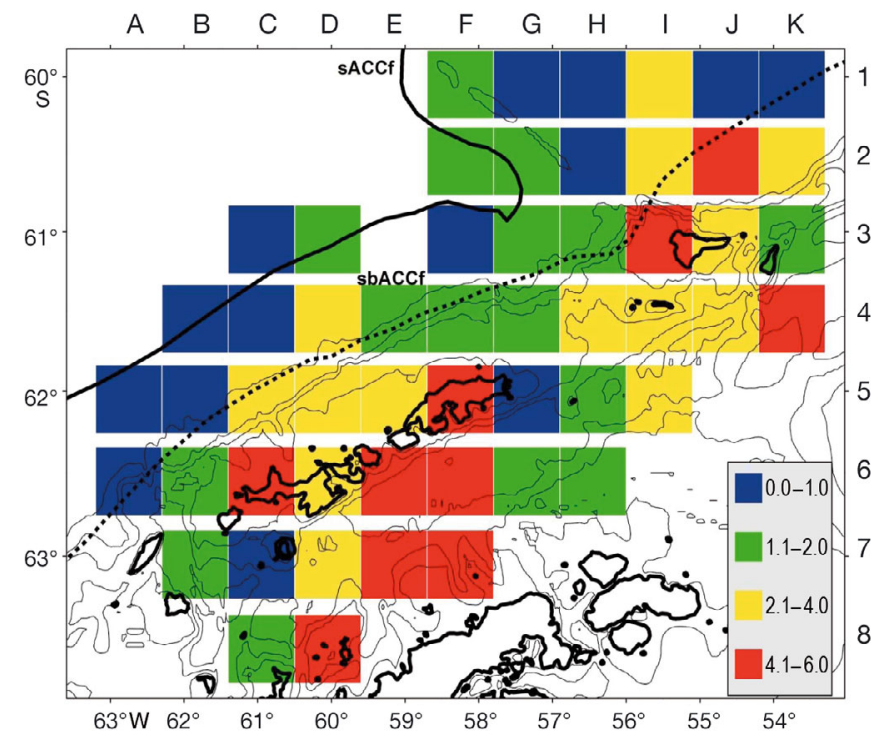

Fig. 8. Summary of the number of species $(n=16)$ abundance hotspots determined by summing the number of species hotspots per cell (see Fig. 4)

penguins, Wilson's storm petrel, south polar skua and southern giant petrel). The highest concentration of neighboring cells with multiple species abundance hotspots (cells D6, E6-7, and F5-7) are located in Bransfield Strait.

\section{Oceanographic determinants of hotspots}

The last application of the hotspot variance metric investigated the relationship between hotspot persistence and distance to land and 2 hydrographic boundaries (Table 4). Several species belonging to the 'Coastal Bransfield Strait' group (Fig. 5) exhibited significant associations (negative) between their spatial persistence and distance to land: humpback whale, Antarctic fur seal, Antarctic fulmar, chinstrap and gentoo penguins, southern giant petrel and south polar skua. None of these species displayed persistent hotspots that were associated with the position of hydrographic boundaries. On the other hand, species from the 'Oceanic Drake Passage' group displayed persistent hotspots that were closely associated with the position of the 2 hydrographic boundaries: fin whale, cape petrel, black-bellied storm petrel, prions, blue petrel, and white-chinned petrel. Interestingly, some species within this group exhibited higher correlation with one oceanographic boundary over the other, suggesting even further niche separation in the oceanic domain. For example, persistent hotspot of prions, blue petrel and white-chinned 
Table 4. Spearman rank correlations for persistence of species abundance and richness relative to distance to land and the southern Antarctic Circumpolar Current front (sACCf) and the southern boundary (sbACCf). Bold values indicate significant association. ${ }^{*}$ Significant negative association. Confidence limits (L95\% and U95\%) are based on a randomization test

\begin{tabular}{|c|c|c|c|c|c|c|c|c|c|}
\hline \multirow[b]{2}{*}{ Variable } & \multicolumn{3}{|c|}{ Distance land } & \multicolumn{3}{|c|}{ Distance sACCf } & \multicolumn{3}{|c|}{ Distance sbACCf } \\
\hline & Rho, p & L95 \%, U95\% & $\mathrm{R}^{2}$ & Rho, p & L95\%, U95\% & $\mathrm{R}^{2}$ & Rho, p & L95 \%, U95 \% & $\mathrm{R}^{2}$ \\
\hline Humpback whale & $-0.57,<0.01^{*}$ & $-0.36,-0.73$ & 0.24 & $0.59,<0.01$ & $0.38,0.74$ & 0.33 & $0.51,<0.01$ & $0.28,0.69$ & 0.26 \\
\hline Fin whale & $0.30,0.02$ & $0.04,0.53$ & 0.04 & $-0.16,0.25$ & $0.11,-0.41$ & 0.007 & $-0.33,0.01^{*}$ & $-0.07,-0.55$ & 0.11 \\
\hline Antarctic fur seal & $-0.48,<0.01^{*}$ & $-0.24,-0.66$ & 0.25 & $0.55,<0.01$ & $0.33,0.71$ & 0.21 & $0.02,0.88$ & $-0.25,0.29$ & 0 \\
\hline Cape petrel & $0.24,0.08$ & $-0.03,0.47$ & 0.02 & $-0.46,<0.01^{*}$ & $-0.22,-0.65$ & 0.15 & $-0.63,<0.01^{*}$ & $-0.43,-0.77$ & 0.31 \\
\hline Antarctic fulmar & $-0.32,0.02^{*}$ & $-0.06,-0.54$ & 0.10 & $0.49,<0.01$ & $0.26,0.67$ & 0.30 & $0.24,0.08$ & $-0.03,0.48$ & 0.20 \\
\hline Black-browed albatross & $0.07,0.62$ & $-0.20,0.33$ & 0.004 & $-0.17,0.22$ & $0.10,-0.42$ & 0.003 & $-0.11,0.42$ & $0.16,-0.37$ & 0.003 \\
\hline Grey-headed albatross & $0.13,0.46$ & $-0.17,0.36$ & 0.0002 & $0.12,0.40$ & $-0.16,0.37$ & 0.02 & $-0.11,0.85$ & $0.15,-0.37$ & 0.02 \\
\hline Wilson's storm petrel & $-0.47,<0.01^{*}$ & $-0.23,-0.65$ & 0.21 & $0.46,<0.01$ & $0.22,0.65$ & 0.25 & $0.37,<0.01$ & $0.12,0.58$ & 0.16 \\
\hline Black-bellied storm petrel & $0.17,0.21$ & $-0.09,0.42$ & 0.007 & $-0.21,0.13$ & $0.06,-0.45$ & 0.05 & $-0.38,<0.01^{*}$ & $-0.12,-0.59$ & 0.15 \\
\hline Prion spp. & $0.65,<0.01$ & $0.46,0.78$ & 0.54 & $-0.50,<0.01^{*}$ & $-0.26,-0.68$ & 0.22 & $-0.30,0.03^{*}$ & $-0.04,-0.53$ & 0.03 \\
\hline Blue petrel & $0.68,<0.01$ & $0.49,0.79$ & 0.51 & $-0.76,<0.01^{*}$ & $-0.62,-0.85$ & 0.45 & $-0.30,0.03^{*}$ & $-0.04,-0.53$ & 0.04 \\
\hline Chinstrap penguin & $-0.51,<0.01^{*}$ & $-0.27,-0.68$ & 0.24 & $0.28,0.03$ & $0.02,0.51$ & 0.09 & $0.14,0.32$ & $-0.14,0.39$ & 0.005 \\
\hline Gentoo penguin & $-0.54,<0.01^{*}$ & $-0.32,-0.71$ & 0.18 & $0.48,<0.01$ & $0.25,0.66$ & 0.13 & $0.32,0.02$ & $0.06,0.54$ & 0.04 \\
\hline White-chinned petrel & $0.60,<0.01$ & $0.39,0.75$ & 0.38 & $-0.57,<0.01^{*}$ & $-0.36,-0.73$ & 0.26 & $-0.29,0.03^{*}$ & $-0.03,-0.52$ & 0.07 \\
\hline Southern giant petrel & $-0.73,<0.01^{*}$ & $-0.58,-0.84$ & 0.45 & $0.52,<0.01$ & $0.29,0.69$ & 0.25 & $0.25,0.07$ & $-0.02,0.48$ & 0.04 \\
\hline South polar skua & $-0.27,0.04^{*}$ & $-0.001,-0.51$ & 0.07 & $0.33,0.01$ & $0.07,0.55$ & 0.15 & $0.41,<0.01$ & $0.16,0.61$ & 0.17 \\
\hline Species richness & $-0.09,0.52$ & $0.18,-0.35$ & 0.003 & $0.07,0.58$ & $-0.19,0.33$ & 0.02 & $-0.12,0.39$ & $0.15,-0.37$ & 0 \\
\hline
\end{tabular}

petrel displayed higher correlation with the location of the southern ACC front than the southern boundary of the ACC front (Table 4, Fig. 4), whereas hotspots of fin whale, cape petrel and black-bellied storm petrel displayed higher association with the southern boundary. Species richness hotspots (Fig. 3) were not significantly associated with distance to land or hydrographic boundaries (Table 4), possibly indicating that persistence of these areas may be attributed to unique biological conditions and complex habitat heterogeneity.

\section{DISCUSSION}

Through years of replicated shipboard surveys and use of a variance-based hotspot metric, this study provides an atlas of persistent species richness and abundance hotspots. Unlike other recent efforts (Nur et al. 2011, Oppel et al. 2012), we used only actual observations and did not include estimated presence based on habitat models. That is, our quantification was based on places where we actually observed aggregations of seabirds and marine mammals, and we did not include those areas predicted to have aggregations on the basis of their habitat characteristics (which confuses what is observed and what is modeled). The quantification of hotspots is important from 2 different perspectives. First, identifying foraging hotspots is important for the conservation of top predators. Be- cause marine ecosystems are highly variable, quantifying persistence of hotspots will benefit development of Marine Protected Areas to effectively conserve top predator species (Hyrenbach et al. 2000, Hooker \& Gerber 2004, Hooker et al. 2011). For example, near the Antarctic Peninsula, knowledge of hotspot locations could be used to minimize conflict between top predators and humans; in particular, spatial allocation of krill fishing activity and vessel traffic patterns (Reid et al. 2004, Hill et al. 2009). Second, it is of interest from a perspective of foraging theory to identify how top predators find prey (Ainley et al. 1992, 2009, Veit 1999, Davoren et al. 2003, Silverman et al. 2004). If top predators memorize the locations of productive feeding areas, then areas we have identified as hotspots are likely to be among those locations memorized. How long individuals spend at such hotspots (Block et al. 2011) and the characteristics of prey aggregations, namely krill within hotspots (Santora et al. 2010, 2012a), remains to be quantified. In the future, blending shipboard surveys and satellite telemetry studies of top predators offers a promising way forward to accomplish estimates of population- and individuallevel use of hotspots.

The novelty of the method we used is twofold. Most importantly, it was based on actual observations of species richness and abundance rather than modeled richness and abundance. The issue here is that top predators only aggregate in a small proportion of the habitats that are actually suitable to them, so that 
regression-style habitat models may overpredict hotspots. Part of the reason for this is that top predators are tracking highly mobile and patchy prey (Davoren et al. 2003). Second, the analysis was not contingent upon knowing any particular statistical distribution of top predator richness or abundance, and in that sense it was a nonparametric analysis. Also, most habitat models predict seabird and mammal abundance based on averages of satellite-based data (e.g. chl a, sea-surface temperature) that often lack the components that were likely attractive to the birds and mammals that were aggregated at the time of sampling (Block et al. 2011, Nur et al. 2011, Oppel et al. 2012). This study differs from others because top predator hotspots were defined based on their persistence; specifically accounting for the frequency of surveys that a particular location exhibited an anomaly richness or abundance value exceeding the long-term spatial mean by 1 SD. Using a similar approach, Suryan et al. (2012) defined persistence of remotely-sensed surface chl a areas (a widely used index of ocean productivity), revealing that the persistence metric explained more variance of seabird density than did mean chl $a$. This study builds on the work of Suryan et al. (2012), but differs because the persistence metric is applied directly to standardized rates of species richness and abundance of seabirds and marine mammals. We advocate the use of this method because it is straightforward and can be easily applied to shipboard surveys of top predators, their prey, and productivity.

\section{Drivers of hotspots}

We did not examine environmental predictors of hotspot occurrence, but rather focused on identifying their location and persistence so they could be examined in future studies combining information on oceanographic features and micronekton collectively to understand trophic transfer in marine environments (Santora et al. 2012b). Potential drivers of persistent top predator hotspots may include features such as abrupt topographies, hydrographic boundaries (Genin 2004), persistent chl a concentration (Suryan et al. 2012) and prey aggregations (Gende \& Sigler 2006, Sigler et al. 2012). However, some environmental features are likely more persistent than others. For example, seamounts and submarine canyons are fixed locations, whereas locations of hydrographic fronts and prey aggregations may move (Hyrenbach et al. 2000, Morato et al. 2010). Future studies ought to apply dynamic habitat mod- els to the hotspot persistence metric to determine what environmental predictors (e.g. bathymetry, sea surface temperature, ch a persistence) explain the spatial distribution and persistence of hotspots (Zydelis et al. 2011, Santora et al. 2012a, 2013). Importantly, hotspots identified in this study reflect summertime conditions when many species are using the area for breeding (e.g. penguins, fur seals) or replenishing energy reserves depleted during migration from wintering grounds (e.g. humpback and fin whales). The persistence of hotspots outside of the summer season remains unknown.

Although krill hotspots are an important predictor of baleen whale hotspots near the Antarctic Peninsula (Santora et al. 2010), future work should assess spatial relationships among krill and top predator hotspots and physical forces simultaneously (Hunt et al. 1998, Santora et al. 2012b, Sigler et al. 2012). Temporal and spatial scales of atmospheric and oceanographic process should be considered when weighing their predictive capabilities on the formation and persistence of biological hotspots (Palacios et al. 2006). For example, eddies are important sources of biological production that may contain high concentrations of chl a and krill (Kahru et al. 2007, Santora et al. 2012a,b), and likely affect spatial and temporal variation in top predator hotspots (Gende \& Sigler 2006, Block et al. 2011). Bathymetry derived circulation patterns and coastal transport processes (e.g. Ekman transport) are likely important for understanding persistence and connectivity of top predator hotspots. Piñones et al. (2011) investigated transport pathways and residence times of water using a regional ocean modeling system (ROMS) to track simulated particles throughout the Antarctic Peninsula, revealing that biological hotspots were sites with the longest particle residence times $(\sim 30 \mathrm{~d})$. If areas with long residence times contain predictable krill concentrations (Hofmann et al. 2004), then ROMS is an important tool for understanding mesoscale transport patterns of krill and connectivity among top predator hotspots among seasonal and inter-annual time scales (Santora et al. 2013).

\section{Spatial organization of hotspots}

Some areas clearly emerge as abundance hotspots because they are located close to large breeding colonies (AMLR 2007, Harris et al. 2011, Santora 2013). Others are nowhere near any known nesting locations (such as for the albatrosses and whales) and are therefore clearly attractive due to their potential 
food resources (e.g. submarine canyons north of Livingston Island; Santora \& Reiss 2011). Our results indicate there are species abundance hotspots that are related to distance to land, in contrast to those related to the position of hydrographic boundaries. This gradient analysis is important for summarizing spatial organization of hotspots relative to the mesoscale structure of the marine environment (Santora et al. 2012a,b). For example, hotspots of fin whales, black-bellied storm petrels and cape petrels are associated with the southern boundary of the ACC, an ecologically important productivity zone throughout the Southern Ocean (Orsi et al. 1995, Tynan 1998). Species hotspots that were associated with the ACC were not associated with distance to land, indicating their affinity for oceanic waters. Distribution of hotspots of seabirds, such as blue petrel, prion species, and white-chinned petrel that do not breed in the study region but hail from colonies originating in sub-Antarctic latitudes, are not associated with islands and are concentrated in the oceanic domain (Hunt et al. 1990, Ainley et al. 1994). Exceptions to this are the black-browed and grey-headed albatross, which also breed on sub-Antarctic islands, and exhibit hotspots near Livingston and Elephant Islands. By contrast, species hotspots identified for chinstrap penguin, gentoo penguin, Antarctic fur seal, south polar skua, southern giant petrel and Wilson's storm petrel were closely associated with distance to land and may indicate probable breeding colony locations (Harris et al. 2011, Santora 2013).

Interestingly, all species richness hotspots displayed persistence values equal to or greater than $50 \%$ of the total time surveyed. This is in contrast to the species abundance hotspots identified, which showed a range of persistence values. In total, 15 species richness hotspots were identified, 9 of which occured near the southern Antarctic Circumpolar Current front, while others were located in proximity to the South Shetland Islands and the location of 2 submarine canyon systems. However, collectively the 15 species richness hotspots were not statistically associated with distance to the ACC or land. The consistently higher level of persistence exhibited by species richness hotspots may indicate there are likely unique physical and biological features specific to each of these locations, and therefore widely attractive to multiple top predator species. For example, krill hotspots located within the ACC, principally composed of large sexually mature krill, are distributed along the shelf-slope coinciding with moderate levels of eddy kinetic energy (Santora et al. 2010, 2012a); areas that attract diverse species groups including procellariid seabirds, toothed cetaceans and mesopelagic fishes (Appendix 1; Barrera-Oro 2002, Santora \& Brown 2010, Santora 2012). Richness hotspots located near land may indicate higher numbers of species that either breed there, or are attracted to the complex bathymetric irregularities (such as submarine canyons) that foster predictable concentrations of krill (Santora \& Reiss 2011); such bathymetric features are typical of the nearshore environment throughout the South Shetland Islands and Antarctic Peninsula region. Future studies should examine each species richness hotspot in greater detail, especially their scale-dependent responses to physical and biological drivers (Hurlbert \& Jetz 2007) to determine if generalities can be made and applied throughout the Southern Ocean.

\section{Hotspots and species interactions}

Formation and maintenance of hotspots are also likely influenced by interactions such as competition and mutualism or facilitation (Reed \& Dobson 1993, Camphuysen \& Webb 1999, Ainley et al. 2006, 2009). Spatial segregation of species abundance hotspots may in fact indicate niche partitioning among species, and relate to difference in prey density and spatial organization (Piatt 1990, Piatt \& Methven 1992, Santora et al. 2010, 2011). We found that several closely related species displayed strikingly different hotspot distribution patterns reflecting oceanic and coastal origins. For example, hotspots of humpback and fin whales-both major krill consumers requiring extremely dense krill patches-displayed virtually no spatial overlap (Santora et al. 2010, Sigler et al. 2012). Hotspots of similar sized cape petrel and Antarctic fulmar also exhibited non-overlapping hotspot patterns. Moreover, Wilson's and blackbellied storm petrel, 2 seemingly identical small petrel species, exhibited hotspots that overlapped very little. Additional characterization of physical and biological features of hotspots could be used to examine potential mechanisms of spatial segregation among sympatric species (Ainley et al. 2009, Santora et al. 2012b).

Species that benefit from one another (e.g. local enhancement; Grünbaum \& Veit 2003) may exhibit higher levels of spatial persistence, having overlapping aggregations within profitable foraging areas. For example, albatross and petrels often aggregate together with pursuit-diving penguins and seals, which are able to exploit a larger portion of the water column, and whose foraging behavior may drive prey 
close to the surface in reach of the flying seabirds (Harrison et al. 1991, Silverman et al. 2004). Our results show that hotspots for black-browed and greyheaded albatrosses also contained fur seal hotspots, and were located near known major fur seal breeding colonies (e.g. Livingston and Seal Islets; cells C5-6 and H3-I2; Fig. 3). Thus, the location of fur seal colonies may be important to albatross conservation because of their facilitatory role in providing access to prey through the action of the seals. Moreover, the abundance hotspots described here may serve as a basis for examining potential competition among seabirds, seals and baleen whales, especially as whale populations continue to rebuild from commercial whaling (Fraser et al. 1992, Ainley et al. 2006, Trivelpiece et al. 2011). For example, hotspots of humpback whales were also closely associated with coastal areas, likely placing them in competition with neighboring seabird and seal colonies (Santora \& Reiss 2011, Santora 2013). Such critically important interspecific interactions need to be taken into account in the implementation of effective conservation measures, as nonlinear impacts of the decline of a single predator can have disproportionate effects (Berec 2010).

\section{Implications for marine spatial management and conservation}

The hotspot patterns presented in this study have implications for marine spatial management in the Southern Ocean. The majority of krill-predator and commercial fishing demand for krill in the Antarctic Peninsula region occurs within 150 to $200 \mathrm{~km}$ from land (Croll \& Tershy 1998, Jones \& Ramm 2004, Reid et al. 2004), coinciding with many of the hotspots identified in this study located near islands. Additionally, the commercial krill catch has increased in recent years, coinciding with new developments in fishing methods enabling nets to remain submerged for weeks and continuously pump krill to factory ships; some estimates suggest krill catches may be as high as $800 \mathrm{t}$ per vessel per day ( $\mathrm{Nicol}$ et al. 2012). To advance spatial management of krill and krillpredators the Commission for the Conservation of Antarctic Marine Living Resources (CCAMLR) developed small-scale management units (SSMUs) to manage catch allocations of krill in small areas ensuring additional protection of important predator foraging areas where fishing vessels may pose potential competition (Constable et al. 2000, Hewitt et al. 2004, Hill et al. 2009). Near the Antarctic Peninsula region, there are 8 SSMUs whose boundaries were established in part due to the foraging range of land-based breeding penguins and seals. The SSMUs did not necessarily take into account the marine distribution of cetaceans, male fur seals, aerial seabirds (e.g. cape petrels, fulmars) and sub-Antarctic breeding seabirds that concentrate in the region. Moreover, potential overlap between krill-predators and fishing vessels was derived from a single shipboard survey spanning a week of survey effort near the Antarctic Peninsula (CCAMLR 2000 Survey; Reid et al. 2004). Due to the high level of temporal and spatial variance in the distribution of seabirds and marine mammals, using shipboard surveys to inform marine spatial management decisions for marine predators should require integration of multiple surveys replicated over many years to quantify mesoscale structure and oceanographic determinants of krill and predator hotspots (Santora et al. 2010, 2012a). Therefore, persistent top predator hotspots identified here should be compared to fluxes in krill abundance (Reiss et al. 2008), fishing pressure (Jones \& Ramm 2004, Nicol et al. 2012), boundaries of existing SSMUs (Hewitt et al. 2004) as well as commercial shipping traffic patterns, which have steadily increased during the past few decades (i.e. tourist ships; Tin et al. 2008, Lynch et al. 2010).

The term hotspot is important for generating awareness and particular attention to species of conservation concern (Myers et al. 2000, Worm et al. 2003, Rodrigues et al. 2006). CCAMLR and BirdLife International are interested in the status of seabird and marine mammal predator populations of ecological and conservation value in the Antarctic Peninsula region. The frequency of occurrence and International Union for Conservation of Nature (IUCN; Rodrigues et al. 2006) status for all 54 taxa recorded during our surveys is presented in Appendix 1. In summary, there were 3 endangered species (hotspots identified for black-browed albatross and fin whale), 4 near threatened (hotspots identified for gentoo penguin) and 5 vulnerable (hotspots identified for grey-headed albatross and white-chinned petrel) species recorded during our surveys. Due to their frequency of occurrence and overall abundance, we were only able to apply the hotspot persistent metric to the 16 most common species inhabiting the study region, some of which may not be candidates for conservation. Species richness hotspots were identified based on sighting rates of all species, keeping in line with the classical concept of a biological hotspot (Myers et al. 2000, Hurlbert \& Jetz 2007). Although some species were sighted less frequently than others 
(Appendix 1), they collectively contributed to our identification of persistent species richness hotspots, indicating the ecology of these areas is likely unique. Therefore, the species richness hotspots we identified are obvious candidates for further evaluation of their vulnerability to anthropogenic disturbance and climate change. Future research ought to characterize and compare these richness hotspots in terms of their oceanography, habitat quality and the prey concentrations they may foster (Worm et al. 2003, Sydeman et al. 2006, Palacios et al. 2006).

In recognition of their vulnerability to human disturbances and climate change, an atlas of Important Bird Areas (IBA) based on breeding bird colonies in the Antarctic Peninsula region highlights many locations throughout South Shetland Island archipelago (Harris et al. 2011). Although identifying land-based IBA is valuable, it does not ensure protection of marine environments where seabirds concentrate their foraging effort and spend the majority of their time (Hooker \& Gerber 2004, Hooker et al. 2011). Generally, foraging seabirds are found in proximity to their breeding colonies, suggesting an inverse function between their at sea abundance and distance to land (Croll \& Tershy 1998). However, non-breeding species of seabirds are not tied to land for provisioning offspring, and some species traveling afar from breeding grounds to distant foraging grounds (e.g. albatross species in this study) indicate that land-based IBA alone will not ensure protection of habitats critical for sustaining seabird populations. The persistent hotspots presented in this study have important implications for designation of marine IBA and should be considered along with land-based IBA for developing Marine Protected Areas in the future. Therefore, future management, conservation and marine spatial planning near the Antarctic Peninsula should benefit from the baseline distribution of persistent multispecies hotspots quantified in this study.

Acknowledgements. We greatly appreciate the dedication of the many US Antarctic Marine Living Resources (AMLR) program field workers for their support over the years. J.A.S. is especially grateful to M. P. Force for his dedication to the observer team. Thanks also to following observers: S. Mitra, A. J. Bernick, D. J. Futuyma, R. Heil, B. Nikula, T. P. White, E. T. Brown and K. Ampela. We thank R. Hewitt, A. Jenkins, C. S. Reiss and G. Watters for their support of the seabird and marine mammal survey team within the AMLR program. The manuscript was improved by comments and feedback from 3 anonymous reviewers, M. F. Sigler, W. J. Sydeman, R. Suryan and V. J Loeb. This study was funded and supported by AMLR contracts to J.A.S. and NSF-OPP grants $(9983751,0337648)$ to R.R.V.

\section{LITERATURE CITED}

Ainley DG, Ribic CA, Fraser WR (1992) Does prey preference affect habitat choice in Antarctic seabirds? Mar Ecol Prog Ser 90:207-221

Ainley DG, Ribic CA, Fraser WR (1994) Ecological structure among migrant and resident seabirds of the ScotiaWeddell Confluence region. J Anim Ecol 63:347-364

Ainley DG, Ballard G, Dugger KM (2006) Competition among penguins and cetaceans reveals trophic cascades in the western Ross Sea, Antarctica. Ecology 87:2080-2093

Ainley DG, Dugger KD, Ford RG, Pierce SD and others (2009) Association of predators and prey at frontal features in the California Current: competition, facilitation and co-occurrence. Mar Ecol Prog Ser 389:271-295

AMLR (2007) United States Antarctic Marine Living Resources Program 2006/2007 field season report: objectives, accomplishments and tentative conclusions. Lipsky JD (ed) NOAA Southwest Fisheries Science Center, Antarctic Ecosystem Research Group, La Jolla. Available at swfsc.noaa.gov/uploadedFiles/Divisions/AERD/Publications/FSR\%202006-07p.pdf

Amos A (2001) A decade of oceanographic variability in summertime near Elephant Island, Antarctica. J Geophys Res 106:22401-22423, doi:10.1029/2000JC000315

Atkinson A, Siegel V, Pakhomov E, Rothery P (2004) Longterm decline in krill stock and increase in salps within the Southern Ocean. Nature 432:100-103

Atkinson A, Siegel V, Pakhomov EA, Rothery P and others (2008) Oceanic circumpolar habitats of Antarctic krill. Mar Ecol Prog Ser 362:1-23

Ballance L, Pitman RL, Hewitt RP, Siniff DB, Trivelpiece WZ, Clapman PJ, Brownell RL Jr (2006) The removal of large whales from the Southern Ocean: evidence for long-term ecosystem effect? In Estes JA, DeMaster DP, Doak DF, Williams TE, Brownell RL Jr (eds) Whales, whaling and ocean ecosystems. University of California Press, Berkeley, p 215-130

Barrera-Oro E (2002) The role of fish in the Antarctic marine food web: differences between inshore and offshore waters in the southern Scotia Arc and west Antarctic Peninsula. Antarct Sci 14:293-309

> Berec L (2010) Impacts of foraging facilitation among predators on predator-prey dynamics. Bull Math Biol 72: 94-121

Block BA, Jonsen ID, Jorgensen SJ, Winship AJ and others (2011) Tracking apex marine predator movements in a dynamic ocean. Nature 475:86-90

Bost CA, Cotté C, Bailleul F, Cherel Y and others (2009) The importance of oceanographic fronts to marine birds and mammals of the southern oceans. J Mar Res 78:363-376

Buckland ST, Anderson DR, Burnham KP, Laake JL (1993) Distance sampling: estimating abundance of biological populations. Chapman \& Hall, London

Camphuysen CJ, Garthe S (2004) Recording foraging seabirds at sea: standardised recording and coding of foraging behavior and multi-species foraging associations. Atlantic Seabirds 6:1-32

Camphuysen CJ, Webb A (1999) Multi-species feeding associations in north sea seabirds: jointly exploiting a patchy environment. Ardea 87:177-198

Constable AJ, de la Mare WK, Agnew DJ, Everson I, Miller D (2000) Managing fisheries to conserve the Antarctic marine ecosystem: practical implementation of the Convention on the Conservation of Antarctic Marine Living 
Resources (CCAMLR). ICES J Mar Sci 57:778-791

Croll DA, Tershy BR (1998) Penguins, fur seals, and fishing: prey requirements and potential competition in the South Shetland Islands, Antarctica. Polar Biol 19:365-374

$>$ Croxall JP, Prince PA (1980) Food, feeding ecology and ecological segregation of seabirds at South Georgia. Biol J Linn Soc 14:103-131

> Davoren GK (2007) Effects of gill-net fishing on marine birds in a biological hotspot in the Northwest Atlantic. Conserv Biol 21:1032-1045

> Davoren GK, Montevecchi WA, Anderson JT (2003) Search strategies of a pursuit-diving marine bird and the persistence of prey patches. Ecol Monogr 73:463-481

Fraser WR, Trivelpiece WZ, Ainley DG, Trivelpiece SG (1992) Increases in Antarctic penguin populations: reduced competition with whales or a loss of sea ice due to environmental warming? Polar Biol 11:525-531

> Gende SM, Sigler MF (2006) Persistence of forage fish 'hot spots' and its association with foraging Steller sea lions (Eumetopias jubatus) in southeast Alaska. Deep-Sea Res II 53:432-441

> Genin A (2004) Bio-physical coupling in the formation of zooplankton and fish aggregations over abrupt topographies. J Mar Syst 50:3-20

Grünbaum D, Veit RR (2003) Foraging behavior of blackbrowed albatrosses exploiting Antarctic krill: densitydependence through local enhancement. Ecology 84: 3265-3275

Harris CM, Carr R, Lorenz K, Jones S (2011) Important bird areas in Antarctica: Antarctic Peninsula, South Shetland Islands, South Orkney Islands - Final Report. Prepared for BirdLife International and the Polar Regions Unit of the UK Foreign \& Commonwealth Office. Environmental Research \& Assessment, Cambridge

Harrison NM, Whitehouse MJ, Heinemann D, Prince PA, Hunt GL, Veit RR (1991) Observations of multispecies seabird flocks around South Georgia. Auk 108:801-810

Hewitt RP, Watters G, Trathan PN, Croxall JP and others (2004) Options for allocating the precautionary catch limit of krill among small-scale management units in the Scotia Sea. CCAMLR Sci 11:81-97

Hill SL, Trathan PN, Agnew DJ (2009) The risk to fishery performance associated with spatially resolved management of Antarctic krill (Euphausia superba) harvesting. ICES J Mar Sci 66:2148-2154

- Hofmann EE, Haskel AGE, Klinck JM, Lascara CM (2004) Lagragian modelling studies of Antarctic krill (Euphausia superba) swarm formations. ICES J Mar Sci 61: 617-631

> Hooker SK, Gerber LR (2004) Marine reserves as a tool for ecosystem-based management: the potential importance of megafauna. Bioscience 54:27-39

> Hooker SK, Cañadas A, Hyrenbach KD, Corrigan C, Polovina JJ, Reeves RR (2011) Making protected area networks effective for marine top-predators. Endang Species Res 13:203-218

Hunt GL, Heinemann D, Veit RR, Heywood RB, Everson I (1990) The distribution, abundance and community structure of marine birds in the southern Drake Passage and Bransfield Strait, Antarctica. Cont Shelf Res 10: 243-257

Hunt GL, Russell RW, Coyle KO, Weingartner T (1998) Comparative foraging ecology of planktivorous auklets in relation to ocean physics and prey availability. Mar Ecol Prog Ser 167:241-259
Hurlbert AH, Jetz W (2007) Species richness, hotspots, and the scale dependence of range maps in ecology and conservation. Proc Natl Acad Sci USA 104:13384-13389

- Hyrenbach KD, Forney KA, Dayton PK (2000) Marine protected areas and ocean basin management. Aquatic Conserv: Mar Freshw Ecosyst 10:437-458

Jones CD, Ramm DC (2004) The commercial harvest of krill in the southwest Atlantic before and during the CCAMLR 2000 Survey. Deep-Sea Res II 51:1421-1434

Kahru M, Mitchell BG, Gille ST, Hewes CD, Hom-Hansen O (2007) Eddies enhance biological production in the Weddell-Scotia Confluence of the Southern Ocean. Geophys Res Lett 34:L14603, doi:10.1029/2007GL030430

Kawaguchi S, Nicol S, Takio K, Naganobu M (2006) Fishing ground selection in the Antarctic krill fishery: trends in patterns across years, seasons and nations. CCAMLR Sci 13:117-141

Laws RM (1977) Seals and whales of the Southern Ocean. Philos Trans R Soc Lond B 279:81-96

Laws RM (1985) Ecology of the Southern Ocean. Am Sci 73: 26-40

Legendre P, Legendre L (1998) Numerical ecology. Elsevier, Amsterdam

Lynch HJ, Crosbie K, Fagan WF, Naveen R (2010) Spatial patterns of tour ship traffic in the Antarctic Peninsula region. Antarct Sci 22:123-130

> Meredith MP, King JC (2005) Rapid climate change in the ocean west of the Antarctic Peninsula during the second half of the 20th century. Geophys Res Lett 32:L19604, doi:10.1029/2005GL024042

Morato T, Hoyle SD, Allain V, Nicol SJ (2010) Seamounts are hotpots of pelagic diversity in the open ocean. Proc Natl Acad Sci USA 107:9707-9711

- Myers N, Mittemeier RA, Mittemeier CG, da Fonseca GAB, Kent J (2000) Biodiversity hotspots for conservation priorities. Nature 403:853-858

> Nicol S, Foster J, Kawaguchi S (2012) The fishery for Antarctic krill - recent developments. Fish Fish 13:30-40

Nur N, Jahncke J, Herzog MP, Howar J and others (2011) Where the wild things are: predicting hotspots of seabird aggregations in the California Current System. Ecol Appl 21:2241-2257

> Oppel S, Meirinho A, Ramírez I, Gardner B, O'Connell AF, Miller PI, Louzao M (2012) Comparison of five modeling techniques to predict the spatial distribution of seabirds. Biol Conserv 156:94-104

> Orsi AH, Whitworth T, Nowlin WD (1995) On the meridional extent and fronts of the Antarctic Circumpolar Current. Deep-Sea Res I 42:641-673

Palacios DM, Bograd SJ, Foley DG, Schwing FB (2006) Oceanographic characteristics of biological hot spots in the North Pacific: a remote sensing perspective. DeepSea Res II 53:250-269

Piatt JF (1990) The aggregative response of common murres and Atlantic puffins to schools of capelin. Stud Avian Biol 14:36-51

Piatt JF, Methven DA (1992) Threshold foraging behavior of baleen whales. Mar Ecol Prog Ser 84:205-210

Piatt JF, Wetzel J, Bell K, DeGange AR and others (2006) Predictable hotspots and foraging habitat of the endangered short-tailed albatross (Phoebastria albatrus) in the North Pacific: implications for conservation. Deep-Sea Res II 53:387-398

Piñones A, Hofmann EE, Dinniman MS, Klinck JM (2011) Lagragian simulation of transport pathways and resi- 
dence times along the western Antarctic Peninsula. Deep-Sea Res II 58:1524-1539

Reed JM, Dobson AP (1993) Behavioral constraints and conservation biology: conspecific attraction and recruitment. Trends Ecol Evol 8:253-256

Reid K, Sims M, White RW, Gillon K (2004) Spatial distribution of predator/prey interactions in the Scotia Sea: implications for measuring predator/fisheries overlap. Deep-Sea Res II 51:1383-1396

Reid K, Davis D, Staniland IJ (2006) Spatial and temporal variability in the fish diet of Antarctic fur seal (Arctocephalus gazella) in the Atlantic sector of the Southern Ocean. Can J Zool 84:1025-1037

Reiss CS, Cossio AM, Loeb V, Demer DA (2008) Variations in the biomass of Antarctic krill (Euphausia superba) around the South Shetland Islands, 1996-2006. ICES J Mar Sci 65:497-508

Rodrigues ASL, Pilgrim JD, Lamoreaux JF, Hoffman M, Brooks TM (2006) The value of the IUCN Red List for conservation. Trends Ecol Evol 21:71-76

Santora JA (2012) Habitat use of hourglass dolphins near the South Shetland Islands, Antarctica. Polar Biol 35: 801-806

Santora JA (2013) Dynamic intra-seasonal habitat use of Antarctic fur seals suggests migratory hotspots near the Antarctic Peninsula. Mar Biol 160:1383-1393

Santora JA, Brown ET (2010) Spatial distribution patterns of Southern bottlenose whales Hyperoodron planifrons near the South Shetland Islands. Mar Mamm Sci 26: 960-968

Santora JA, Reiss CS (2011) Geospatial variability of krill and top-predators within an Antarctic submarine canyon system. Mar Biol 158:2527-2540

Santora JA, Reiss CS, Cossio AC, Veit RR (2009) Interannual spatial variability of Antarctic krill (Euphausia superba) influences seabird foraging behavior near Elephant Island, Antarctica. Fish Oceanogr 18:20-35

Santora JA, Reiss CS, Loeb VJ, Veit RR (2010) Spatial association between hotspots of baleen whales and demographic patterns of Antarctic krill Euphausia superba suggests size-dependent predation. Mar Ecol Prog Ser 405:255-269

Santora JA, Ralston S, Sydeman WJ (2011) Spatial organization of krill and seabirds in the central California Current. ICES J Mar Sci 68:1391-1402

Santora JA, Sydeman WJ, Schroeder ID, Reiss CS and others (2012a) Krill space: a comparative assessment of mesoscale structuring in polar and temperate marine ecosystems. ICES J Mar Sci 69:1317-1327

Santora JA, Field JC, Schroeder ID, Sakuma KM, Wells BK, Sydeman WJ (2012b) Spatial ecology of krill, micronekton and top predators in the central California Current System: implications for defining ecologically important areas. Prog Oceanogr 106:154-174

Santora JA, Sydeman WJ, Messié M, Chai F and others (2013) Triple check: observations verify structural real- ism of an ocean ecosystem model. Geophys Res Lett 40: 1367-1372

Sigler MF, Kuletz KJ, Ressler PH, Friday NA, Wilson CD, Zerbini AN (2012) Marine predators and persistent prey in the southeast Bering Sea. Deep-Sea Res II 65-70: 292-303

Silverman ED, Veit RR, Nevitt GA (2004) Nearest neighbors as foraging cues: information transfer in a patchy environment. Mar Ecol Prog Ser 277:25-36

Southwell C, Paxton CGM, Borchers D, Boveng P, De La Mare W (2008) Taking account of dependent species in management of the Southern Ocean krill fishery: estimating crabeater seal abundance off east Antarctica. J Appl Ecol 45:622-631

Suryan RM, Santora JA, Sydeman WJ (2012) New approach for using remotely-sensed chlorophyll a to identify seabird hotspots. Mar Ecol Prog Ser 451:213-225

Sydeman WJ, Thompson SA, Kitaysky A (2012) Seabirds and climate change: roadmap for the future. Mar Ecol Prog Ser 454:107-117

Sydeman WJ, Brodeur RD, Grimes CB, Bychkov AS, Mckinnel S (2006) Marine habitat 'hotspots' and their use by migratory species and top predators in the North Pacific Ocean: Introduction. Deep-Sea Res II 53:247-249

Thompson AF, Heywood KJ, Thorpe SE, Renner AHH, Trasvina A (2009) Surface circulation at the tip of the Antarctic Peninsula from drifters. J Phys Oceanogr 39: 3-26

Tin T, Fleming ZL, Hughes KA, Ainley DG and others (2008) Impacts of local human activities on the Antarctic environment. Antarct Sci 21:3-33

Tittensor DP, Mora C, Jetz A, Lotze HK, Ricard D, Vanden Berghe E, Worm B (2010) Global patterns and predictors of marine biodiveristy across taxa. Nature 466: 1098-1101

Trivelpiece WZT, Hinke J, Miller AK, Reiss CS, Trivelpiece SG, Watters GM (2011) Variability in krill biomass links harvesting and climate warning to penguin populations in Antarctica. Proc Natl Acad Sci USA 108: 7625-7628

Tynan CT (1998) Ecological importance of the southern boundary of the Antarctic Circumpolar Current. Nature 392:708-710

Veit RR (1999) Behavioral responses by foraging petrels to swarms of Antarctic krill. Ardea 87:41-50

Worm B, Lotze HK, Myers RA (2003) Predator diversity hotspots in the blue ocean. Proc Natl Acad Sci USA 100: 9884-9888

Yen PPW, Sydeman WJ, Bograd SJ, Hyrenbach KD (2006) Spring-time distributions of migratory marine birds in the southern California Current: oceanic eddy associations and coastal habitat hotspots over 17 years. Deep-Sea Res II 53:399-418

Zydelis R, Lewison RL, Shaffer SA, Moore JE and others (2011) Dynamic habitat models: using telemetry data to project fisheries bycatch. Proc R Soc B 278:3191-3200 
Appendix 1. Species observed during 14 US Antarctic Marine Living Resource (AMLR) surveys January - March, 2003-2011 (sorted alphabetically within frequency of surveys). Conservation status is provided by the International Union for Conservation of Nature (IUCN; www.iucnredlist.org); see Rodrigues et al. 2006 for details about the IUCN Red List

\begin{tabular}{|c|c|c|c|}
\hline Name & & $\begin{array}{l}\text { Surveys } \\
\text { observed }\end{array}$ & $\begin{array}{l}\text { IUCN } \\
\text { status }\end{array}$ \\
\hline Antarctic fulmar & Fulmarus glacialoides & 14 & Least Concern \\
\hline Antarctic fur seal & Arctocephalus gazella & 14 & Least Concern \\
\hline Antarctic minke whale & Balaenoptera bonaerensis & 14 & Data Deficient \\
\hline Antarctic prion & Pachyptila desolata & 14 & Least Concern \\
\hline Antarctic tern & Sterna vittata & 14 & Least Concern \\
\hline Black-browed albatross & Thalassarche melanophrys & 14 & Endangered \\
\hline Black-bellied storm petrel & Fregetta tropica & 14 & Least Concern \\
\hline Blue petrel & Halobaena caerulea & 14 & Least Concern \\
\hline Brown skua & Catharacta antarctica & 14 & Least Concern \\
\hline Cape petrel & Daption capense & 14 & Least Concern \\
\hline Chinstrap penguin & Pygoscelis antarctica & 14 & Least Concern \\
\hline Fin whale & Balaenoptera physalus & 14 & Endangered \\
\hline Grey-headed albatross & Thalassarche chrysostoma & 14 & Vulnerable \\
\hline Humpback whale & Megaptera novaeangliae & 14 & Least Concern \\
\hline Light-mantled albatross & Phoebetria palpebrata & 14 & Near Threatened \\
\hline Southern giant petrel & Macronectes giganteus & 14 & Least Concern \\
\hline South polar skua & Stercorarius maccormicki & 14 & Least Concern \\
\hline Wandering albatross & Diomedea exulans & 14 & Vulnerable \\
\hline Wilson's storm petrel & Oceanites oceanicus & 14 & Least Concern \\
\hline Gentoo penguin & Pygoscelis papua & 13 & Near Threatened \\
\hline Northern giant petrel & Macronectes halli & 13 & Least Concern \\
\hline White-chinned petrel & Procellaria aequinoctialis & 13 & Vulnerable \\
\hline Soft-plumaged petrel & Pterodroma mollis & 12 & Least Concern \\
\hline Kelp gull & Larus dominicanus & 11 & Least Concern \\
\hline Southern bottlenose whale & Hyperoodon planifrons & 11 & Least Concern \\
\hline Antarctic petrel & Thalassoica antarctica & 10 & Least Concern \\
\hline Arctic tern & Sterna paradisaea & 10 & Least Concern \\
\hline Macaroni penguin & Eudyptes chrysolophus & 10 & Vulnerable \\
\hline Thin-billed prion & Pachyptila belcheri & 10 & Least Concern \\
\hline Adelie penguin & Pygoscelis adeliae & 9 & Least Concern \\
\hline Killer whale & Orcinus orca & 9 & Data Deficient \\
\hline Snowy sheathbill & Chionis albus & 8 & Least Concern \\
\hline Snow petrel & Pagodroma nivea & 8 & Least Concern \\
\hline Antarctic shag & Phalacrocorax bransfieldensis & 7 & Not Evaluated \\
\hline Common diving petrel & Pelecanoides urinatrix & 7 & Least Concern \\
\hline Hourglass dolphin & Lagenorhynchus cruciger & 7 & Least Concern \\
\hline Southern elephant seal & Mirounga leonina & 7 & Least Concern \\
\hline Southern royal albatross & Diomedea epomophora & 7 & Vulnerable \\
\hline Weddell seal & Leptonychotes weddellii & 7 & Least Concern \\
\hline Leopard seal & Hydrurga leptonyx & 6 & Least Concern \\
\hline Long-finned pilot whale & Globicephala melas & 6 & Data Deficient \\
\hline Southern right whale & Eubalaena australis & 5 & Least Concern \\
\hline Crabeater seal & Lobodon carcinophaga & 4 & Least Concern \\
\hline Sooty shearwater & Puffinus griseus & 4 & Near Threatened \\
\hline Kerguelen petrel & Lugensa brevirostris & 3 & Least Concern \\
\hline White-headed petrel & Pterodroma lessonii & 3 & Least Concern \\
\hline Parasitic jaeger & Stercorarius parasiticus & 2 & Least Concern \\
\hline Emperor penguin & Aptenodytes forsteri & 1 & Least Concern \\
\hline Fairy prion & Pachyptila turtur & 1 & Least Concern \\
\hline Gray's beaked whale & Mesoplodon grayi & 1 & Data Deficient \\
\hline King penguin & Aptenodytes patagonicus & 1 & Least Concern \\
\hline Mottled petrel & Pterodroma inexpectata & 1 & Near Threatened \\
\hline South Georgia diving petrel & Pelecanoides georgicus & 1 & Least Concern \\
\hline Sooty albatross & Phoebetria fusca & 1 & Endangered \\
\hline
\end{tabular}

